\title{
The Role of Lactic Acid on Wound Healing, Cell Growth, Cell Cycle Kinetics, and Gene Expression of Cultured Junctional Epithelium Cells in the Pathophysiology of Periodontal Disease
}

\author{
Taichi Ishikawa ${ }^{1, *} \mathbb{\infty}$, Daisuke Sasaki ${ }^{2}$, Ryo Aizawa $^{3}$, Matsuo Yamamoto ${ }^{3}$, Takashi Yaegashi ${ }^{2}$, Tarou Irié ${ }^{4}$ and \\ Minoru Sasaki ${ }^{1} \mathbb{D}$
}

1 Division of Molecular Microbiology, Department of Microbiology, Iwate Medical University, 1-1-1 Idai-dori, Yahaba-Cho, Morioka 028-3694, Japan; msasaki@iwate-med.ac.jp

2 Division of Periodontology, Department of Conservative Dentistry, School of Dentistry, Iwate Medical University, 1-3-27 Chuo-dori, Morioka 020-8505, Japan; daisukes@iwate-med.ac.jp (D.S.); tyaegasi@iwate-med.ac.jp (T.Y.)

3 Department of Periodontology, School of Dentistry, Showa University, 2-1-1 Kitasenzoku, Ohta-ku, Tokyo 145-8515, Japan; r-aizawa@dent.showa-u.ac.jp (R.A.); yamamoto-m@dent.showa-u.ac.jp (M.Y.)

4 Division of Anatomical and Cellular Pathology, Department of Pathology, Iwate Medical University, 1-1-1 Idai-dori, Yahaba-Cho, Morioka 028-3694, Japan; tarou@iwate-med.ac.jp

* Correspondence: tishikaw@iwate-med.ac.jp; Tel.: +81-19-651-5111; Fax: +81-19-908-8011

Citation: Ishikawa, T.; Sasaki, D.; Aizawa, R.; Yamamoto, M.; Yaegashi, T.; Irié, T.; Sasaki, M. The Role of Lactic Acid on Wound Healing, Cell Growth, Cell Cycle Kinetics, and Gene Expression of Cultured Junctional Epithelium Cells in the Pathophysiology of Periodontal Disease. Pathogens 2021, 10, 1507. https://doi.org/10.3390/pathogens 10111507

Academic Editor: Lawrence S. Young

Received: 20 October 2021

Accepted: 17 November 2021

Published: 18 November 2021

Publisher's Note: MDPI stays neutral with regard to jurisdictional claims in published maps and institutional affiliations.

Copyright: (c) 2021 by the authors. Licensee MDPI, Basel, Switzerland. This article is an open access article distributed under the terms and conditions of the Creative Commons Attribution (CC BY) license (https:// creativecommons.org/licenses/by/ $4.0 /)$.

\begin{abstract}
Lactic acid (LA) is short-chain fatty acid, such as butyric acid and propionic acid, that is produced as a metabolite of lactic acid bacteria, including periodontopathic bacteria. These shortchain fatty acids have positive effects on human health but can also have negative effects, such as the promotion of periodontal disease (PD), which is caused by periodontal pathogens present in the gingival sulcus. PD is characterized by apical migration of junctional epithelium, deepening of pockets, and alveolar bone loss. Thus, the junctional epithelial cells that form the bottom of the gingival sulcus are extremely important in investigating the pathophysiology of PD. The aim of this study was to investigate the effect of LA on wound healing, cell growth, cell cycle kinetics, and gene expression of cultured junctional epithelium cells. The results showed that stimulation with $10 \mathrm{mM}$ LA slowed wound healing of the junctional epithelial cell layer and arrested the cell cycle in the G0/G1 (early cell cycle) phase, thereby inhibiting cell growth. However, cell destruction was not observed. LA also enhanced mRNA expression of integrin $\alpha 5$, interleukin (IL)-6, IL-8, intercellular adhesion molecule- 1 , and receptor activator of nuclear factor kappa-B ligand. The results of this study suggest that stimulation of junctional epithelial cells with high concentrations of LA could exacerbate PD, similarly to butyric acid and propionic acid.
\end{abstract}

Keywords: cell cycle; junctional epithelium; lactic acid; periodontal disease; short-chain fatty acids

\section{Introduction}

It is well known that lactic acid bacteria (LABs), as probiotics, convey beneficial effects to human health by inhibition of pathogenic microorganisms, immune regulation, antiallergic activities, and antagonism [1,2]. For example, LABs are reported to enhance host immunity and prevent many diseases, including cancer [3], as well as produce bacteriocin, which strongly inhibits the growth and proliferation of Streptococcus mutans, the major causative agent of caries formation, and Porphylomonas gingivalis, a periodontal pathogen [4]. In addition, LAB, which includes Actinomyces, Bacteroides, Lactobacillus, and Fusobacterium, reside in the intestinal tract and oral cavity [5,6]. However, lactic acid (LA), a metabolite of LABs, promotes caries formation [7], and high concentrations in the blood and cerebrospinal fluid can damage tissues and nerves, ultimately resulting in death [8-10]. Thus, depending on location, LABs can have both beneficial and detrimental effects on the host [11]. LA is a short-chain fatty acid, sharing biochemical characteristics with butyric 
acid, propionic acid, acetic acid, and formic acid, that can promote and prolong gingival inflammation $[6,12]$. In vitro experiments have confirmed that butyric acid and propionic acid are involved in the adhesion, growth, cell cycle, and protein synthesis of gingival fibroblasts [13]. The gingival sulcus of the periodontitis patient frequently exhibits local butyric, propionic, and LA concentrations of approximately 1 to $30 \mathrm{mM}$ [14]. At low concentrations, LA slows apoptosis of polymorphonuclear leukocytes and has an opposite effect at high concentrations [14]. Butyric acid, in particular, is associated with periodontitis [15-17] but is also reported to have beneficial health effects, such as suppression of colitis via the induction of regulatory $\mathrm{T}$ cell differentiation, especially in the intestinal tract $[18,19]$. Thus, like butyric acid, LA can have adverse effects depending on the site and concentration, although the detailed association with periodontal disease (PD) remains unclear.

$\mathrm{PD}$ is caused by bacteria that form dental plaques in the gingival sulcus, such as periodontal pathogenic bacteria and oral streptococci, in association with pathogenic factors produced by these plaque bacteria, such as protease and fimbriae, and the host immune response [20-22]. Clinically, it is characterized by apical migration of epithelium (junctional epithelium) along the surface of the root to the root tip, loss of attachment, deepening of pockets, and loss of alveolar bone [23]. Short-chain fatty acids, including LA, are produced in dental plaque with increased concentrations in the gingival crevicular fluid of patients with severe periodontitis as compared to healthy controls [24,25]. However, the effects of LA on PD, as opposed to butyric acid and propionic acid, remain unclear. In addition, the junctional epithelium has different properties from gingival fibroblasts and other cells used in previous studies of PD [26,27]. Therefore, the aim of the present study was to investigate the effects of LA on wound healing, cell growth, cell cycle kinetics, and gene expression of cultured junctional epithelium (JE-1) cells, a newly established junctional epithelial cell line [28]. This study will be useful for elucidating the pathophysiology of periodontal disease and could be utilized in future clinical practice.

\section{Results}

\subsection{LA Inhibited Cell Mobility and Proliferation}

As shown in Figure 1A, cells migrated to the cell-free area and completely filled the gap after 1 day (control and $1 \mathrm{mM} \mathrm{LA}$ ), while the gap of the cells cultured with $10 \mathrm{mM}$ LA remained until day 2. Under all culture conditions, relatively few dead and floating cells were observed on day 2 . In the group treated with $10 \mathrm{mM} \mathrm{LA}$, the cell-free area on day 1 was approximately $65 \%$ of that on day 0 (Figure 1B). 
A

Day 0

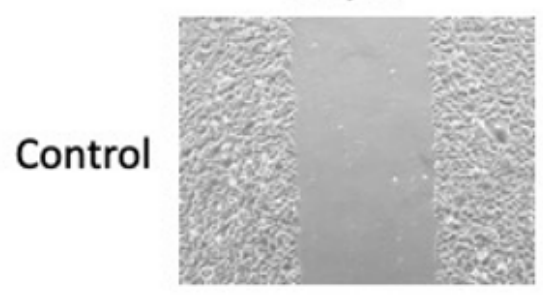

$1 \mathrm{mM}$
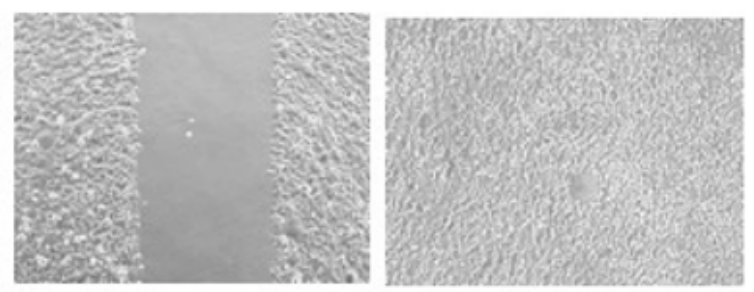

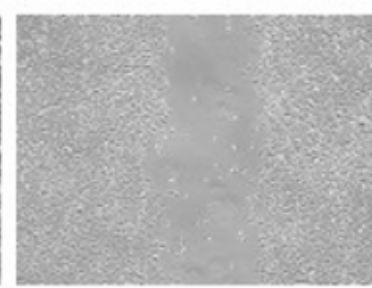

Day 1
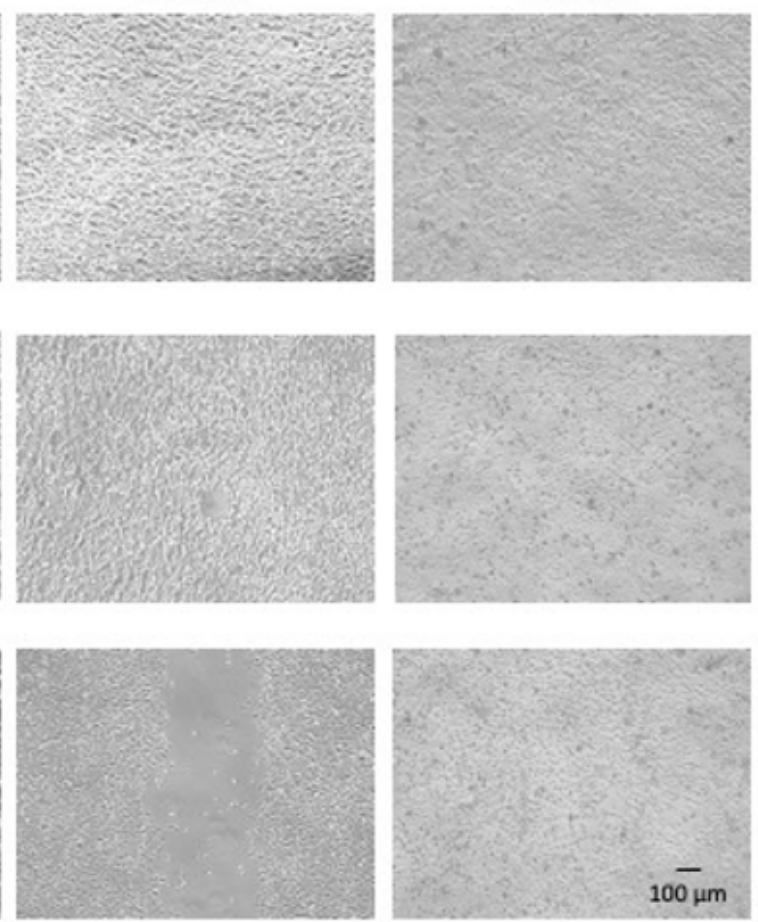

B

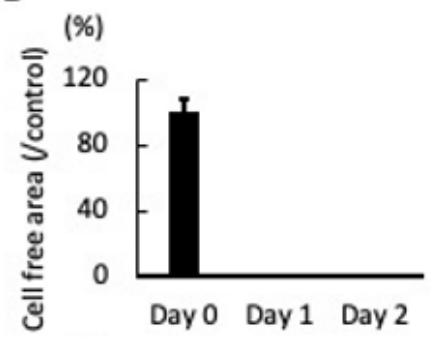

(\%)

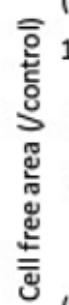

(\%)

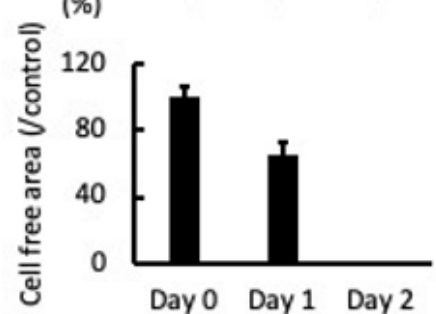

Figure 1. Photomicrographs of the scratch assay on days 0,1 , and 2 (A). Cells were incubated in fresh medium supplemented with 1 or $10 \mathrm{mM}$ LA. Representative photomicrographs of four independent experiments are shown. The cell-free areas were measured every $24 \mathrm{~h}$ from day 0 to day 2 (B). Values are presented as the mean \pm SD of four independent experiments. Scale bar $=100 \mu \mathrm{m}$.

\subsection{LA Affected Cell Proliferation}

The amount of total RNA extracted from the cells cultured with $10 \mathrm{mM}$ LA was significantly reduced after 24 and $48 \mathrm{~h}$ compared to the respective controls (Figure 2A,B). Cell proliferation was completely inhibited by $10 \mathrm{mM}$ LA from day 1 to day 3 (Figure 2C). However, there was no difference in LDH activity at 24 and $48 \mathrm{~h}$, apart from the group treated with Triton X 100, which destroyed all cells (Figure 2D). LDH activity at $48 \mathrm{~h}$ was slightly higher than at $24 \mathrm{~h}$ (Figure 2C,D). 
A

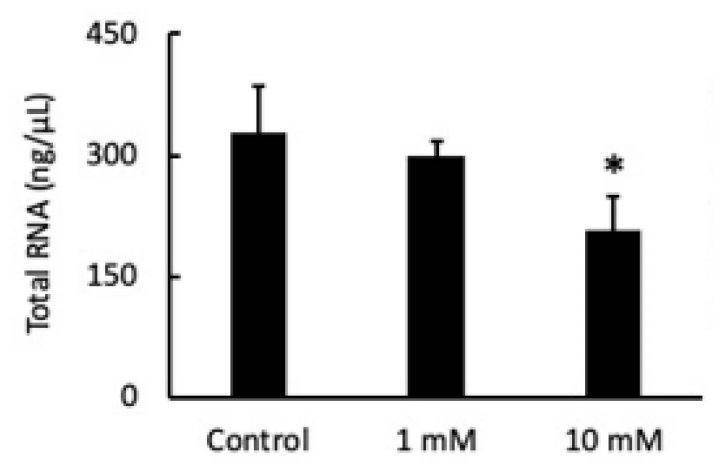

C
B

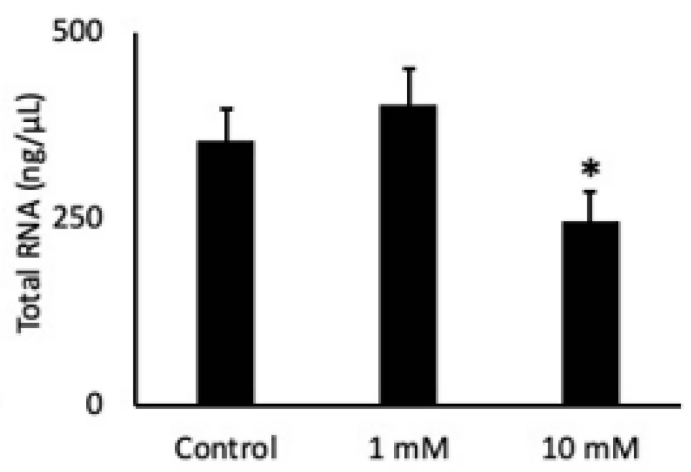

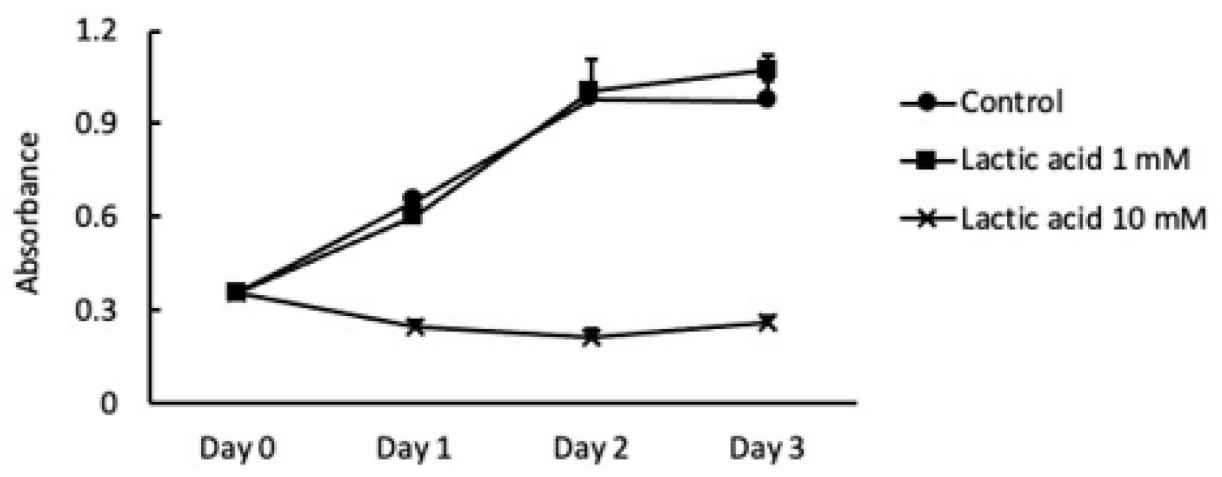

D

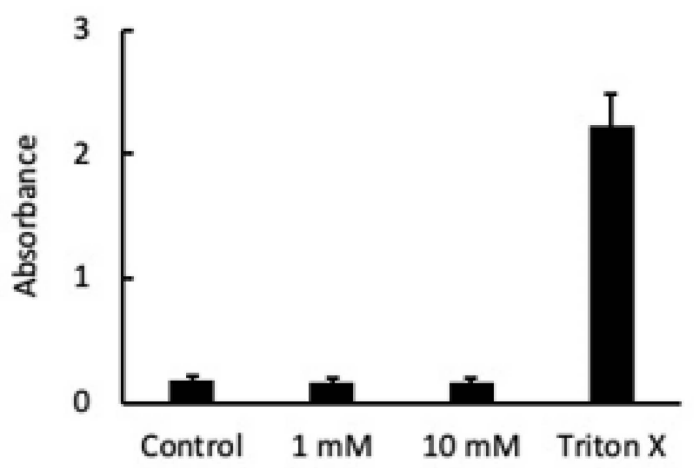

E

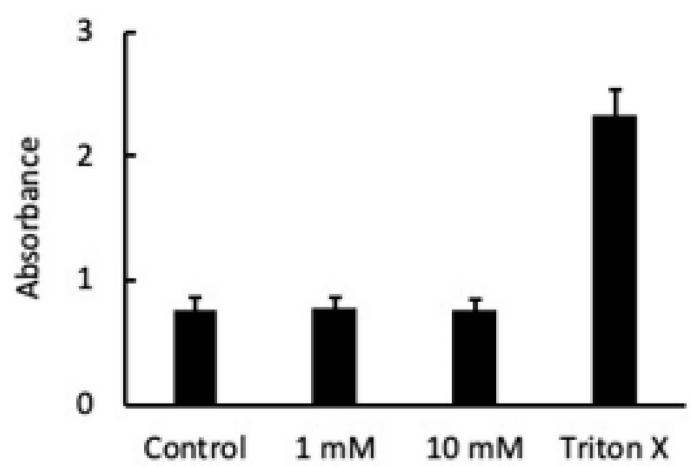

Figure 2. The cells were cultured in fresh medium supplemented with 1 or $10 \mathrm{mM}$ LA or fresh medium only (as a control). The bars indicate the amount of total RNA extracted from the cultures at $24 \mathrm{~h}(\mathbf{A})$ and $48 \mathrm{~h}(\mathbf{B})$. Values are presented as the mean \pm SD of six independent experiments. Cell proliferation was assessed by measuring absorbance. $(\bullet),(\mathbb{\square})$, and $(\times)$ represent the control, $1 \mathrm{mM} \mathrm{LA}$, and $10 \mathrm{mM}$ LA groups, respectively (C). Values are presented as the mean $\pm \mathrm{SD}$ of eight independent experiments. Cell viability was measured in terms of LDH activity at $24 \mathrm{~h}(\mathbf{D})$ and $48 \mathrm{~h}(\mathbf{E})$. An $1 \%$ Triton $\mathrm{X}$ 100 was used to measure the maximum enzyme activity. ${ }^{*} p<0.05 \mathrm{vs}$. control cells $(0 \mathrm{mM})$. Values are presented as the mean \pm SD of five independent experiments.

\subsection{LA Interrupted Progression of the Cell Cycle}

There was no significant difference in the morphology or number of cells cultured with $1 \mathrm{mM}$ LA for $24 \mathrm{~h}$ as compared to the control. However, when cultured with $10 \mathrm{mM}$ LA for $24 \mathrm{~h}$, there was an inhibition in the proliferation of cells and most were small and round (Figure 3A). In addition, the characteristics were remarkable, and the gap was relatively 
wide among the cells cultured with $10 \mathrm{mM}$ LA for $48 \mathrm{~h}$ (Figure 3A). The results of color pixel analysis showed that a significantly large proportion of cells cultured with $10 \mathrm{mM}$ LA for $24 \mathrm{~h}$ were in the G0/G1 phase (yellow color) (Figure 3B). In contrast, relatively few cells cultured with $1 \mathrm{mM}$ LA and those in the control group $(0 \mathrm{mM})$ were in the $S$ phase (green color) (Figure 3C). There was no significant difference in the relatively low proportion of cells in the G2/M phase cells (blue color) among the groups (Figure 3D).

A

Day 1

Day 2
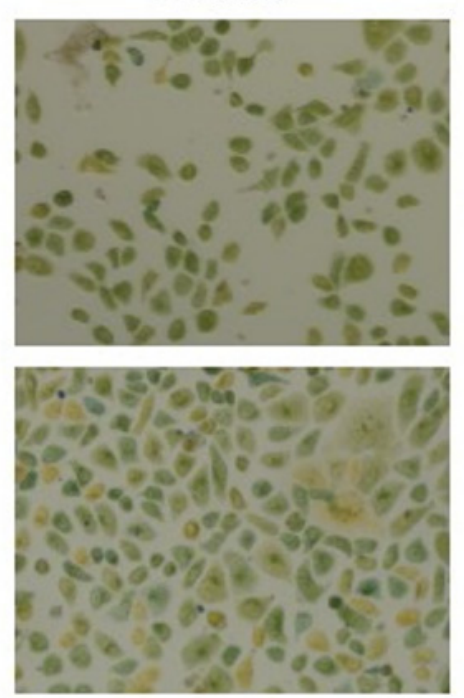

B

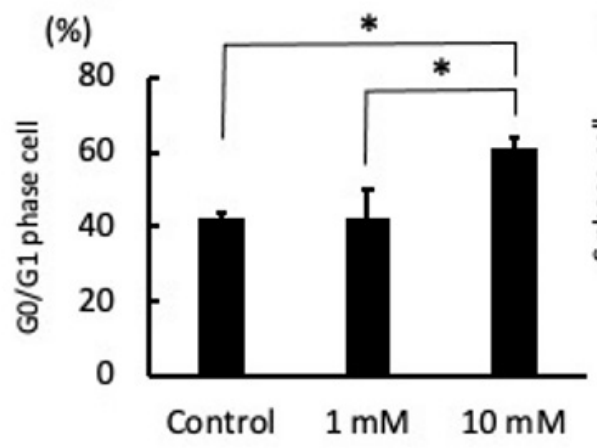

$1 \mathrm{mM}$
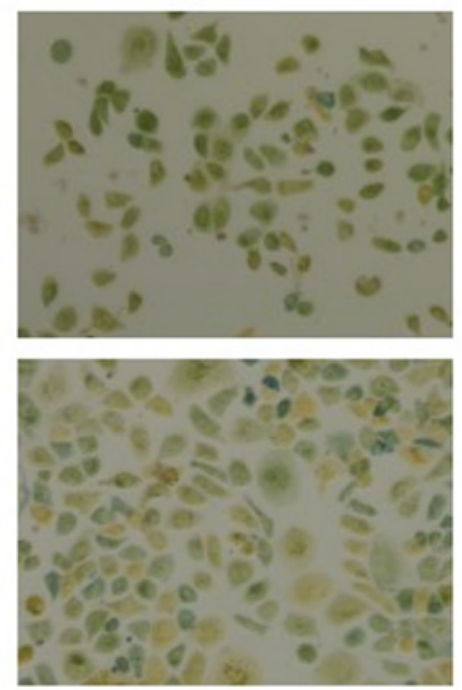

C

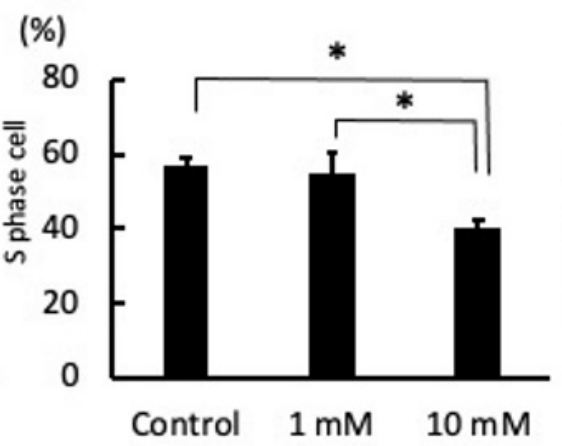

$10 \mathrm{mM}$
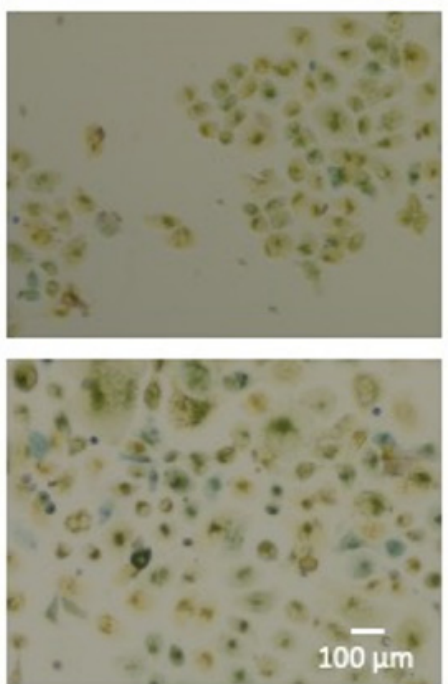

D

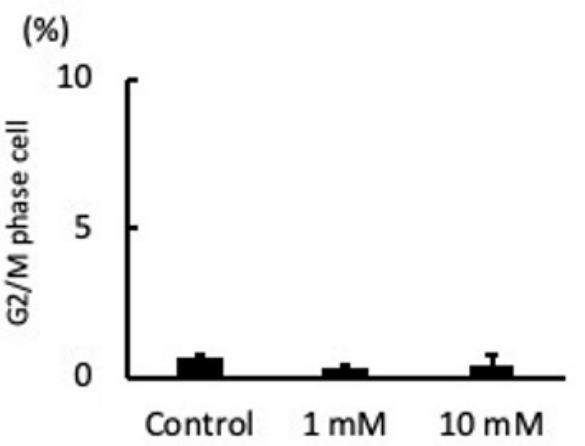

Figure 3. Photomicrographs of the cell cycle on days 1 and 2 (A). The cells were cultured with fresh medium supplemented with 1 or $10 \mathrm{mM}$ LA or fresh medium only (as a control). Representative photomicrographs of four independent experiments are shown. The phase of the cell cycle was determined by color pixel analysis. The percentages of cells in the G0/G1 phase (B), S phase (C), and G2/M phase (D) are shown. ${ }^{*} p<0.05$. Values are presented as the mean $\pm \mathrm{SD}$ of four independent experiments. Scale bar $=100 \mu \mathrm{m}$.

\subsection{LA Influenced Gene Expression}

Integrin $\alpha 5$ expression levels were greater in cells cultured with $10 \mathrm{mM}$ LA than those treated with $0 \mathrm{mM}$ (control) and $1 \mathrm{mM} \mathrm{LA}$, while there was no significant difference in integrin $\alpha \mathrm{V}$ expression levels (Figure 4A,B). IL-6 and IL-8 expression levels were significantly higher in cells treated with $10 \mathrm{mM}$ LA than the control. In particular, IL-8 expression was about 3.5-fold greater than the control group and 2.6-fold greater than cells cultured with $1 \mathrm{mM}$ LA (Figure 4C,D). ICAM-1 and RANKL expression levels were also significantly increased in cells cultured with $10 \mathrm{mM} \mathrm{LA}$ as compared to those treated with $0 \mathrm{mM}$ (control) and $1 \mathrm{mM}$ LA (Figure 4E,F). 
A

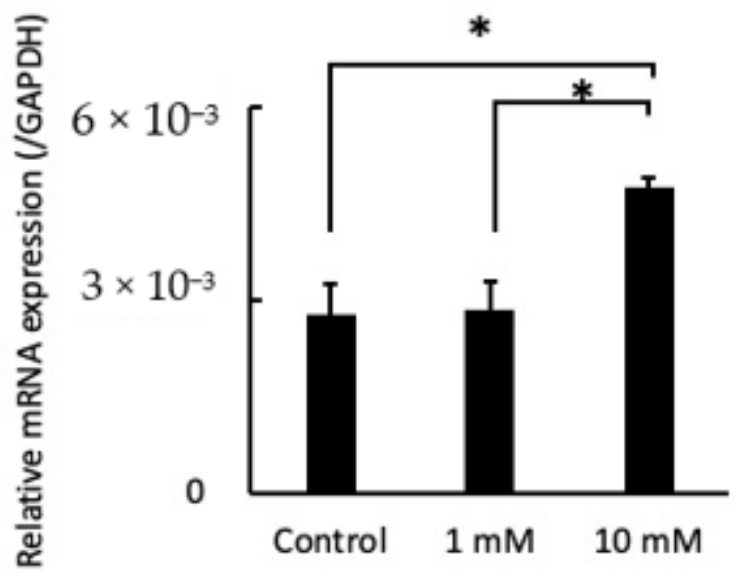

C

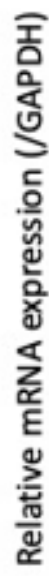
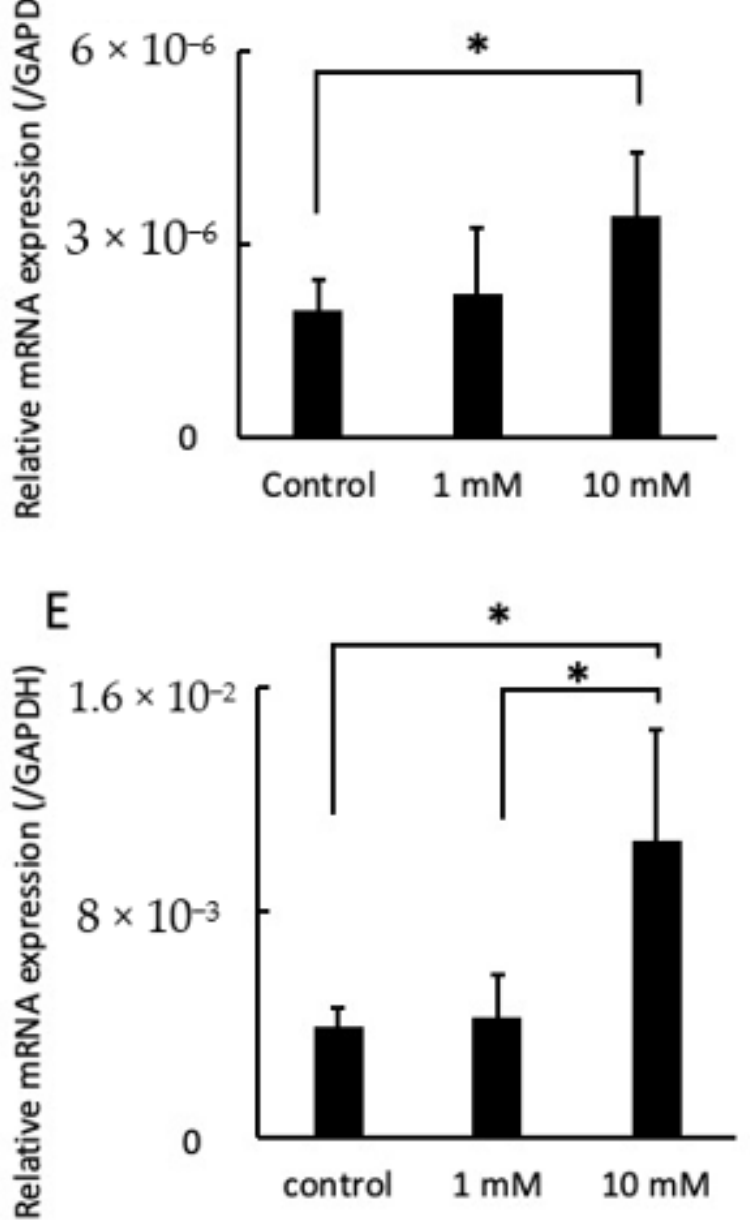

B

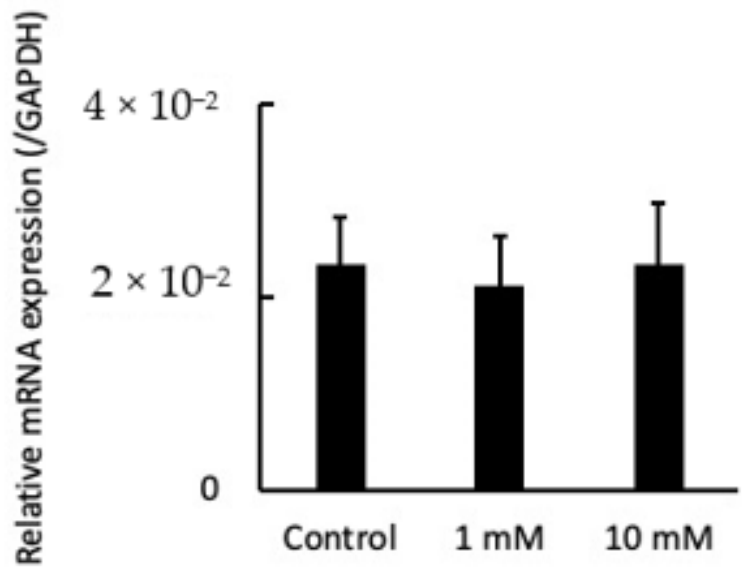

D

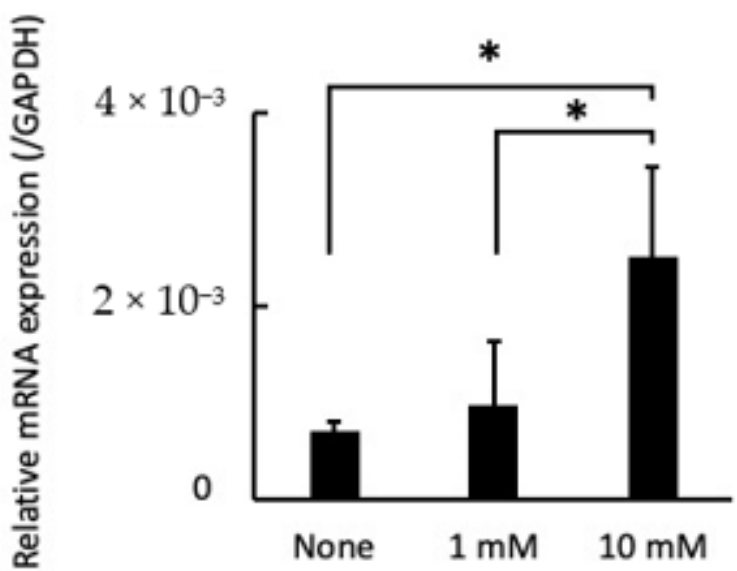

F

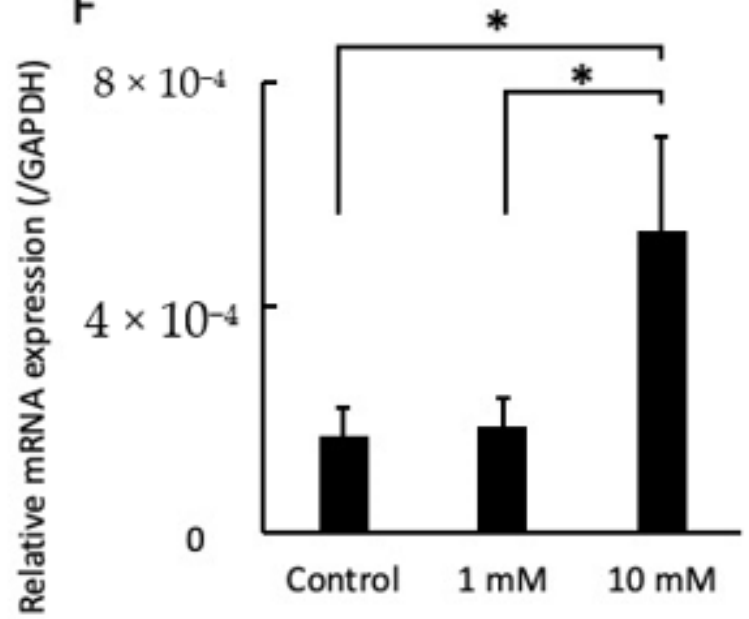

Figure 4. Effects of LA on mRNA expression levels of integrin $\alpha 5$ (A), integrin $\alpha \mathrm{V}$ (B), IL-6 (C), IL-8 (D), ICAM-1 (E), and RANKL (F). The cells were cultured with fresh medium supplemented with 1 or $10 \mathrm{mM}$ LA or fresh medium only (as a control). Total RNA was isolated from cells after culturing for $24 \mathrm{~h}$. mRNA levels are shown relative to GAPDH, the internal control. ${ }^{*} p<0.05$. Values are presented as the mean $\pm \mathrm{SD}$ of six independent experiments. 


\section{Discussion}

In this study, the effect of LA, a common metabolite of some oral bacteria, on PD was investigated. At first, scratch assay results showed that LA delayed wound healing of the junctional epithelium. Normally, the onset of PD involves proteases and other factors produced by periodontopathic bacteria that destroy the junctional epithelial cell layer and accelerate inflammation, which allows periodontopathic bacteria to invade tissues [29,30]. Therefore, from the results of this experiment, the delay in healing of the junctional epithelial cell layer due to the influence of LA may facilitate tissue invasion by oral bacteria and exacerbate PD. Although the cells were not destroyed by LA, proliferation was clearly suppressed, suggesting that a delayed cell cycle of junctional epithelial cells affected wound healing. Further cell cycle analysis revealed that a relatively high proportion of cells stimulated with a high concentration $(10 \mathrm{mM})$ of LA were in the G0/G1 phase, indicating that LA arrested the cell cycle in the G0/G1 phase. This finding is similar to that of a previous study [13], which reported that butyric acid and propionic acid inhibit progression of the cell cycle of gingival fibroblasts. Although the time was delayed, the wound closed, suggesting that cell migration may have occurred; thus, the expression patterns of integrin $\alpha 5$ and $\alpha \mathrm{V}$, which are involved in wound healing (cell migration), were investigated. The results suggest that JE- 1 cells produce integrin $\alpha 5$ to promote wound healing, although the addition of LA inhibited progression of the cell cycle, as evidenced by the relatively low density and number of cells. The small amount of total RNA isolated from cells stimulated with a high concentration of LA support this finding.

The results of qRT-PCR showed that the effect of LA may be linked to the progression of periodontitis because the expression of IL- 6 was increased. It is well known that IL-6 promotes the differentiation of $\mathrm{B}$ cells into plasma cells, is involved in antibody production, and plays a central role in the inflammatory response. Furthermore, it has been reported that fibroblasts in gingival connective tissue produce IL-6 in response to calprotectin and may cause the progression of periodontitis via crosstalk between fibroblasts and macrophages [31]. Hence, IL-6 derived from the junctional epithelium might also contribute to this reaction. In addition, mRNA expression of the chemokine IL-8 was increased. IL-8 is an important factor in the regulation of the inflammatory response [32], promotes the migration of neutrophils from the peripheral blood to areas of inflammation in the gingival sulcus [33]. From the results of qRT-PCR that ICAM-1 expression was increased, the effect of LA on junctional epithelial cells may induce the migration of leukocytes into tissues and accelerate inflammation. ICAM- 1 is an adhesive protein on the surface of the gingival and junctional epithelial cells that is an important component of adhesion between cells and the extracellular matrix, as well as cell signaling, inflammation, and immune responses in the development of periodontitis [34]. Increased mRNA and protein levels of ICAM-1 have also been observed in gingival epithelial cells stimulated with butyric acid [16]. However, further research is needed because the effects of cytokines vary from cell to tissue.

RANKL is the most important factor in osteoclast differentiation and function, is highly associated with alveolar bone loss in periodontal lesions [35].In addition, RANKL, which promotes osteoclast formation, is produced by osteoblasts, osteocytes, periodontal ligament cells, and gingival epithelial cells of the periodontium [36]. Interestingly, LA significantly increased mRNA expression levels of RANKL. Therefore, a very important finding of this study was that a high concentration of LA could accelerate alveolar bone loss. However, since this was an in vitro study, it is unclear whether the same effect will occur in vivo. More experiments that are in line with actual clinical practice using a mouse model are required.

The results of the present study suggest that LA produced by bacteria in subgingival plaques suppresses cell proliferation and delays wound healing by inhibiting the cell cycle of JE-1 cells at high concentrations. Further, stimulation of the junctional epithelium with a high concentration of LA exacerbates inflammation via excessive production of inflammatory cytokines and adhesion factors and could be directly involved in alveolar bone loss. Therefore, LA, like butyric acid, has a positive effect on human health but 
can also have a harmful effect locally such as the promotion of PD. The effects of LA on the junctional epithelium revealed in this study may help clarify some of the onset and progression of PD and may suggest new treatments and preventions.

\section{Materials and Methods}

\subsection{Cell Treatment}

Murine junctional epithelial (JE-1) cells, which were established by Matsuo Yamamoto (Showa University, Tokyo, Japan [28]), were cultured in CnT-Prime epithelial culture medium (CELLnTEC Advanced Cell Systems AG, Bern, Switzerland) under a humidified atmosphere of $5 \% \mathrm{CO}_{2} / 95 \%$ air at $37{ }^{\circ} \mathrm{C}$. At $80 \%$ confluence, the cells were detached from the culture dishes using TrypLE ${ }^{\mathrm{TM}}$ recombinant enzyme (Gibco, Carlsbad, CA, USA).

\subsection{Scratch Assay}

JE-1 cells were grown in the wells of 24-well cell culture plates until $100 \%$ confluence. Then, the cell monolayer was scratched using a pipette tip, washed with phosphatebuffered saline to remove floating cells, and incubated in CnT-Prime medium supplemented with 1 or $10 \mathrm{mM}$ LA or fresh medium only (as a control). Finally, the cells were photographed on days 0,1 , and 2 using an inverted stage microscope (BZ-9000; Keyence, Osaka, Japan) equipped with a digital camera at $100 \times$ magnification. The cell-free area was calculated using ImageJ software 1.53k (https://imagej.net/ (accessed on 1 September 2021)).

\subsection{RNA Extraction}

The cells were seeded into the wells of 24 -well cell culture plates at $7.0 \times 10^{4}$ cell/well in CnT-Prime medium and cultured for $48 \mathrm{~h}$. The medium was changed to either fresh medium supplemented with 1 or $10 \mathrm{mM}$ LA or fresh medium only (as a control). Following incubation for 24 and $48 \mathrm{~h}$, total RNA was extracted from the cells using an RNeassy Mini Kit (Qiagen $\mathrm{GmbH}$, Hilden, Germany) in accordance with the manufacturer's instructions. The RNA concentration was then measured with a NanoDrop ${ }^{\mathrm{TM}}$ Lite spectrophotometer (NanoDrop Technologies, LLC, Wilmington, DE, USA).

\subsection{Cell Proliferation Assay}

Cell proliferation was analyzed using the Cell Counting Kit-8 (Wako, Osaka, Japan) in accordance with the manufacturer's instructions. The cells were plated into the wells of 96-well cell culture plates at $5 \times 10^{3}$ cell/well in CnT-Prime medium and incubated for $24 \mathrm{~h}$. Afterward, the medium was changed to fresh medium supplemented with 1 or $10 \mathrm{mM}$ LA or fresh medium only (as a control). The absorbance was recorded every $24 \mathrm{~h}$ for 4 days (including day 0) with a SpectraMax ${ }^{\circledR}$ M2 microplate reader (Molecular Devices, LLC, San Jose, CA, USA). The optical density of the wells was measured at a wavelength of $450 \mathrm{~nm}$ with a reference wavelength of $600 \mathrm{~nm}$.

\subsection{Cell Viability Assay}

Cell viability was analyzed using the lactate dehydrogenase (LDH) Cytotoxicity Detection Kit (TaKaRa Bio, Inc., Shiga, Japan) in accordance with the manufacturer's instructions. The cells were incubated in the wells of 24 -well cell culture plates at $7.0 \times 10^{4}$ cell/well in CnT-Prime medium. At 24 and $48 \mathrm{~h}$, the supernatants were collected and treated with $1 \%$ Triton X 100 prior to measurement of maximum enzyme activity. Absorbance was measured using a SpectraMax ${ }^{\circledR}$ M2 microplate reader (Molecular Devices, LLC.). The optical density of the wells was measured at a wavelength of $490 \mathrm{~nm}$ with a reference wavelength of $600 \mathrm{~nm}$.

\subsection{Cell Cycle Assay}

The phase of the cell cycle was measured using the Cell-Clock Cell Cycle Assay Kit (Biocolor Ltd., Carrickfergus, Northern Ireland) in accordance with the manufacturer's 
instructions. The cells were pre-cultured in the wells of 24-well cell culture plates at $5 \times 10^{4}$ cell/well in CnT-Prime medium for $24 \mathrm{~h}$. Afterward, the medium was changed to fresh medium supplemented with 1 or $10 \mathrm{mM} \mathrm{LA}$ or fresh medium only (as a control). Then, live cells were labeled with the dye reagent of the Cell-Clock Cell Cycle Assay Kit at 24 and $48 \mathrm{~h}$. Images were obtained with an inverted stage microscope (Dmi1; Leica Camera AG, Wetzlar, Germany) equipped with a digital camera at $100 \times$ magnification. The phase of the cell cycle was determined by color pixel analysis using ImageJ software 1.53k (https:/ /imagej.net/ (accessed on 1 September 2021)).

\subsection{Real-Time Quantitative Reverse-Transcription Polymerase Chain Reaction (qRT-PCR)}

Total RNA was extracted from cells cultured in fresh medium supplemented with 1 or $10 \mathrm{mM}$ LA or fresh medium only (as a control) for $24 \mathrm{~h}$, reverse transcribed into cDNA using PrimeScript RT Master Mix (TaKaRa bio, Inc.) with TB Green Premix Ex Taq II polymerase (TaKaRa Bio, Inc.) and amplified with a Thermal Cycler Dice Real-Time System (TaKaRa Bio, Inc.) using primer pairs specific for integrin $\alpha 5$, integrin $\alpha \mathrm{V}$, interleukin (IL)-6, IL-8, intercellular adhesion molecule-1 (ICAM-1), receptor activator of nuclear factor kappa-B ligand (RANKL), and glyceraldehyde-3-phosphate dehydrogenase (GAPDH), as an internal control. Gene expression levels were normalized to that of GAPDH. The qRT-PCR cycling conditions consisted of an initial denaturation step at $95{ }^{\circ} \mathrm{C}$ for $30 \mathrm{~s}$ followed by 40 cycles of denaturation at $95{ }^{\circ} \mathrm{C}$ for $5 \mathrm{~s}$ and annealing and extension at $60{ }^{\circ} \mathrm{C}$ for $30 \mathrm{~s}$. Melting curve (dissociation curve) analysis was performed to confirm the specificity of primers.

\subsection{Statistical Analysis}

Data are presented as the mean \pm standard deviation (SD). Statistical analyses were conducted with MacTKV3 software (Esumi Co., Ltd., Tokyo, Japan). The Shapiro-Wilk test was used to confirm the normality of the data (Figures 2-4), while the Bartlett's test was performed to assess homoscedasticity (Figures 2-4). For groups with homoscedasticity, Bonferroni's multiple comparison test was used after one-way analysis of variance (Figures 2 and 3, and Figure 4A-C). For groups with heteroscedasticity, the GamesHowell multiple comparison test was used after Welch's analysis of variance (Figure 4D-F). A probability $(p)$ value of $<0.05$ was considered statistically significant.

Author Contributions: Conceptualization, T.I. (Taichi Ishikawa); data curation, D.S. and T.I. (Taichi Ishikawa); formal analysis, T.I.; funding acquisition, T.I. (Taichi Ishikawa); supervision, T.I. (Tarou Irié), M.S., and T.Y.; writing—original draft, T.I. (Taichi Ishikawa); writing-review and editing, R.A. and M.Y. All authors have read and agreed to the published version of the manuscript.

Funding: The study was partially supported by KAKENHI (grant No. 20K09925) from the Japan Society for the Promotion of Science (Tokyo, Japan).

Institutional Review Board Statement: Not applicable.

Informed Consent Statement: Not applicable.

Data Availability Statement: All the data obtained in this research are described in the manuscript.

Acknowledgments: The authors would like to thank Tomohito Hanasaka (Technical Support Center for Life Science Research, Iwate Medical University, Iwate, Japan) for help with the photomicrographs and the members of the Department of Periodontology, School of Dentistry, Showa University.

Conflicts of Interest: The authors have no conflict of interest to declare.

\section{References}

1. Masood, M.I.; Qadir, M.I.; Shirazi, J.H.; Khan, I.U. Beneficial effects of lactic acid bacteria on human beings. Crit. Rev. Microbiol. 2010, 37, 91-98. [CrossRef] [PubMed]

2. Zielińska, D.; Kolożyn-Krajewska, D. Food-Origin Lactic Acid Bacteria May Exhibit Probiotic Properties: Review. BioMed Res. Int. 2018, 2018, 5063185. [CrossRef] [PubMed] 
3. Rajoka, M.S.R.; Shi, J.; Zhu, J.; Shao, D.; Huang, Q.; Yang, H.; Jin, M. Capacity of lactic acid bacteria in immunity enhancement and cancer prevention. Appl. Microbiol. Biotechnol. 2017, 101, 35-45. [CrossRef]

4. Lai, W.-K.; Lu, Y.-C.; Hsieh, C.-R.; Wei, C.-K.; Tsai, Y.-H.; Chang, F.-R.; Chan, Y. Developing Lactic Acid Bacteria as an Oral Healthy Food. Life 2021, 11, 268. [CrossRef]

5. Tap, J.; Mondot, S.; Levenez, F.; Pelletier, E.; Caron, C.; Furet, J.-P.; Ugarte, E.; Muñoz-Tamayo, R.; Paslier, D.L.; Nalin, R.; et al Towards the human intestinal microbiota phylogenetic core. Environ. Microbiol. 2009, 11, 2574-2584. [CrossRef]

6. Niederman, R.; Zhang, J.; Kashket, S. Short-Chain Carboxylic-Acid-Stimulated, PMN-Mediated Gingival Inflammation. Crit. Rev. Oral Biol. Med. 1997, 8, 269-290. [CrossRef]

7. Dung, S.-Z.; Gregory, R.; Li, Y.; Stookey, G. Effect of Lactic Acid and Proteolytic Enzymes on the Release of Organic Matrix Components from Human Root Dentin. Caries Res. 1995, 29, 483-489. [CrossRef]

8. Andersen, L.W.; Mackenhauer, J.; Roberts, J.C.; Berg, K.M.; Cocchi, M.N.; Donnino, M.W. Etiology and therapeutic approach to elevated lactate levels. Mayo Clin. Proc. 2013, 88, 1127-1140. [CrossRef]

9. Kraut, J.A.; Madias, N.E. Lactic acidosis. N. Engl. J. Med. 2014, 371, 2309-2319. [CrossRef]

10. Kalimo, H.; Rehncrona, S.; Söderfeldt, B.; Olsson, Y.; Siesjö, B.K. Brain Lactic Acidosis and Ischemic Cell Damage: 2. Histopathology. Br. J. Pharmacol. 1981, 1, 313-327. [CrossRef] [PubMed]

11. Luo, Y.; Li, L.; Chen, X.; Gou, H.; Yan, K.; Xu, Y. Effects of lactate in immunosuppression and inflammation: Progress and prospects. Int. Rev. Immunol. 2021. [CrossRef]

12. Kashket, S.; Zhang, J.; Niederman, R. Gingival Inflammation Induced by Food and Short-chain Carboxylic Acids. J. Dent. Res. 1998, 77, 412-417. [CrossRef] [PubMed]

13. Jeng, J.-H.; Chan, C.-P.; Ho, Y.-S.; Lan, W.-H.; Hsieh, C.-C.; Chang, M.-C. Effects of Butyrate and Propionate on the Adhesion, Growth, Cell Cycle Kinetics, and Protein Synthesis of Cultured Human Gingival Fibroblasts. J. Periodontol. 1999, 70, $1435-1442$. [CrossRef]

14. Stehle, H.W.; Leblebicioglu, B.; Walters, J.D. Short-Chain Carboxylic Acids Produced by Gram-Negative Anaerobic Bacteria Can Accelerate or Delay Polymorphonuclear Leukocyte Apoptosis in Vitro. J. Periodontol. 2001, 72, 1059-1063. [CrossRef] [PubMed]

15. Shirasugi, M.; Nakagawa, M.; Nishioka, K.; Yamamoto, T.; Nakaya, T.; Kanamura, N. Relationship between periodontal disease and butyric acid produced by periodontopathic bacteria. Inflamm. Regen. 2018, 38, 23. [CrossRef] [PubMed]

16. Takigawa, S.; Sugano, N.; Nishihara, R.; Koshi, R.; Murai, M.; Yoshinuma, N.; Ochiai, K.; Ito, K. The effect of butyric acid on adhesion molecule expression by human gingival epithelial cells. J. Periodontal Res. 2008, 43, 386-390. [CrossRef] [PubMed]

17. Ishikawa, T.; Sasaki, D.; Aizawa, R.; Shimoyama, Y.; Yamamoto, M.; Irié, T.; Sasaki, M. Effect of Butyric Acid in the Proliferation and Migration of Junctional Epithelium in the Progression of Periodontitis: An In Vitro Study. Dent. J. 2021, 9, 44. [CrossRef] [PubMed]

18. Zhou, D.; Pan, Q.; Liu, X.; Yang, R.; Chen, Y.; Liu, C.; Fan, J. Clostridium butyricumB1 alleviates high-fat diet-induced steatohepatitis in mice via enterohepatic immunoregulation. J. Gastroenterol. Hepatol. 2017, 32, 1640-1648. [CrossRef]

19. Furusawa, Y.; Obata, Y.; Fukuda, S.; Endo, T.A.; Nakato, G.; Takahashi, D.; Nakanishi, Y.; Uetake, C.; Kato, K.; Kato, T.; et al. Commensal microbe-derived butyrate induces the differentiation of colonic regulatory T cells. Nature 2013, 504, 446-450. [CrossRef]

20. Shah, H.; Gharbia, S.; O’Toole, C. Assessment of the Relative Cytotoxicity ofPorphyromonas gingivalisCells, Products, and Components on Human Epithelial Cell Lines. J. Periodontol. 1992, 63, 44-51. [CrossRef]

21. Xu, W.; Zhou, W.; Wang, H.; Liang, S. Roles of Porphyromonas gingivalis and its virulence factors in periodontitis. Adv. Protein Chem. Struct. Biol. 2020, 120, 45-84. [CrossRef]

22. Hajishengallis, G.; Korostoff, J.M. Revisiting the Page \& Schroeder model: The good, the bad and the unknowns in the periodontal host response 40 years later. Periodontol. 2000 2017, 75, 116-151. [CrossRef] [PubMed]

23. Kinane, D.F. Causation and pathogenesis of periodontal disease. Periodontol. 2000 2001, 25, 8-20. [CrossRef] [PubMed]

24. Lu, R.; Meng, H.; Gao, X.; Xu, L.; Feng, X. Effect of non-surgical periodontal treatment on short chain fatty acid levels in gingival crevicular fluid of patients with generalized aggressive periodontitis. J. Periodontal Res. 2014, 49, 574-583. [CrossRef] [PubMed]

25. Qiqiang, L.; Huanxin, M.; Xuejun, G. Longitudinal study of volatile fatty acids in the gingival crevicular fluid of patients with periodontitis before and after nonsurgical therapy. J. Periodontal Res. 2012, 47, 740-749. [CrossRef] [PubMed]

26. Schroeder, H.E.; Listgarten, M.A. The Junctional Epithelium: From Strength to Defense. J. Dent. Res. 2003, 82, 158-161. [CrossRef] [PubMed]

27. Yajima-Himuro, S.; Oshima, M.; Yamamoto, G.; Ogawa, M.; Furuya, M.; Tanaka, J.; Nishii, K.; Mishima, K.; Tachikawa, T.; Tsuji, T.; et al. The junctional epithelium originates from the odontogenic epithelium of an erupted tooth. Sci. Rep. 2015, 4, 4867. [CrossRef]

28. Seki, T.; Aizawa, R.; Tanaka, J.; Yajima-Himuro, S.; Kato, M.; Tanaka, K.; Mishima, K.; Yamamoto, M. Establishment of mouse gingival junctional epithelial cell line using a bioengineered tooth system. Biochem. Biophys. Res. Commun. 2018, 497, 167-172. [CrossRef]

29. Dzink, J.L.; Tanner, A.C.R.; Haffajee, A.D.; Socransky, S.S. Gram negative species associated with active destructive periodontal lesions. J. Clin. Periodontol. 1985, 12, 648-659. [CrossRef]

30. Socransky, S.S.; Haffajee, A.D.; Cugini, M.A.; Smith, C.; Kent, R.L., Jr. Microbial complexes in subgingival plaque. J. Clin. Periodontol. 1998, 25, 134-144. [CrossRef] 
31. Naruishi, K.; Nagata, T. Biological effects of interleukin-6 on Gingival Fibroblasts: Cytokine regulation in periodontitis. J. Cell. Physiol. 2018, 233, 6393-6400. [CrossRef]

32. Bickel, M. The role of interleukin-8 in inflammation and mechanisms of regulation. J. Periodontol. 1993, 64, 456-460. [PubMed]

33. Mlachkova, A.; Popova, C.; Doseva, V. Presence of IL-8 Gene Polymorphism and IL-8 Serum Levels in Patients with Chronic Periodontitis - Literature Review. Folia Medica 2020, 62, 253-257. [CrossRef] [PubMed]

34. Wang, L.; Li, X.-H.; Ning, W.-C. Evaluation of ICAM-1 and VCAM-1 Gene Polymorphisms in Patients with Periodontal Disease. Med. Sci. Monit. 2016, 22, 2386-2391. [CrossRef] [PubMed]

35. Tsukasaki, M.; Takayanagi, H. Osteoimmunology: Evolving concepts in bone-immune interactions in health and disease. Nat. Rev. Immunol. 2019, 19, 626-642. [CrossRef] [PubMed]

36. Tsukasaki, M. RANKL and osteoimmunology in periodontitis. J. Bone Miner. Metab. 2021, 39, 82-90. [CrossRef] 